\title{
Amylase and Biosurfactant Production from Bacillus species
}

\author{
Olusegun Richard Adeoyo* \\ Department of Microbiology, Adekunle Ajasin University, P.M.B. 001, \\ Akungba-Akoko, Ondo State, Nigeria \\ *Corresponding author
}

\begin{tabular}{l} 
K e y w o r d s \\
Amylases, \\
Biosurfactants, \\
Agricultural soil, \\
Bacillus species \\
\hline Article Info \\
$\begin{array}{l}\text { Accepted: } \\
26 \text { April } 2020 \\
\text { Available Online: } \\
10 \text { May } 2020\end{array}$
\end{tabular}

\section{A B S T R A C T}

Most Bacillus species have ability to produce secondary metabolites such as amylases and biosurfactants. This study was carried out to determine the amylase and boisurfactant production potentials of some Bacillus species obtained from agricultural soil. Soil samples were collected from agricultural research farm of Adekunle Ajasin University, Akungba-Akoko, Ondo State, Nigeria. All isolates were identified based on the morphological and biochemical characteristics using Bergey's manual of determinative bacteriology. Amylase-producing Bacillus species were selected and screened on soluble starch agar while biosurfactant activity was determined by three methods; blood haemolysis, oil spreading, and drop-collapse tests. The extent of amylase activity of each isolate was determined quantitatively using dinitrosalicylic acid (DNSA) assay method. A total of ten (10) Bacillus species were isolated and identified from the samples. These isolates include two B. subtilis (AMY5 and AMY13), B. mycoides, two B. polymyxa (AMY2 and AMY12), B. azotoformans B. licheniformis, B. megaterium, B. pumilus and B. cereus. The enzyme assay results indicated that $B$. megaterium (Isolate code: AMY17) had the best activity value of $1.12 \mu \mathrm{mol} / \mathrm{min} / \mathrm{mL}$ while $B$. cereus had the least value 0.27 $\mu \mathrm{mol} / \mathrm{min} / \mathrm{mL}$. All Bacillus species demonstrated great potentials for biosurfactant production except B. subtilis (AMY10). Overall, B. licheniformis (AMY17) and B. subtilis (AMY5) had the highest biosurfactant activity. Therefore, Bacillus species are promising sources of amylases and biosurfactants for the bioeconomy and their use should be encouraged.

\section{Introduction}

Amylases are biocatalytic proteins that act on starch molecules and hydrolyze starch to produce various products such as dextrin and smaller polymers composed of glucose units (Natasa et al., 2011; Mohammed and Mastan, 2013). Enzymes are considered to be important in modern biotechnology with its applications ranging from food to detergent and paper making industries (Pandey et al., 2000). Microbial amylases can be derived from microorganisms, a good number of microbial amylases are now available for commercial use and they have almost replaced chemical hydrolysis of starch in starch processing and related industries (Hussain et al., 2013). Amylases can be 
classified into three: (a) alpha amylase, (b) beta amylase and (c) gamma amylase. Alpha amylase: is an amylolytic enzyme that breaks down $\alpha$, 1-4-glucosidic: linkages of starch into an endo form and produces oligosaccharides (Parka and Son, 2007). Beta amylase: acts on the non-reducing end by cleaving two glucose units (maltose) at a time (Bijttebier et al., 2007). Gamma amylase: it cleaves the last $\alpha$-(1-4)-glycosidic and $\alpha-(1-$ 6)-glycosidic linkages at the non-reducing end of amylose and amylopectin to yield glucose (Adeoyo et al., 2019). Gamma ( $\gamma$ )-amylase has been reported to be active in acidic environments (Kumar and Satyanarayana, 2009). Amylase is majorly produced by bacterial species of Bacillus (Muralikrishna and Nirmala, 2005), and B. subtilis and $B$. licheniformis are among the species that have been widely studied (Nidhi et al., 2005).

Amylase from microbial sources can be produced in large quantities to meet the high industrial and market demands, and the diversity of microbes as the source material for bio-based products (such as enzyme production) is gaining ground every day. Although, amylases can be derived from other sources, such as plants, and animals, but because of the short growth period, biochemical diversity and the ease with which enzyme concentrations can be increased by nutritional, environmental conditions and genetic manipulation, makes enzymes from microbial sources much better (Oliveira et al., 2007; Mishra and Behera, 2008). Bacteria are a more dominant group of microorganisms in soil (Bodour et al., 2003) with population of about a hundred thousand to several hundred millions for a gram of soil (Rangaswami and Bagyarag, 2004).

Biosurfactants are surface active compounds that accumulate at the boundary between two immiscible fluids or between a fluid and a solid. They reduce the repulsive forces (tension) between two different phases (liquid/air or liquid/liquid) which allow them to mix and thus enhance their solubility properties (Cheng et al., 2008; Perfumo et al., 2010; Fracchia et al., 2012). They are amphiphilic compounds consisting of hydrophilic and hydrophobic domains. The hydrophilic domain can be carbohydrate, amino acid, phosphate group or some other compounds whereas the hydrophobic domain usually is a long chain fatty acid (Lang, 2002). Microorganisms have been reported to produce several classes of biosurfactants such as glycolipids, phospholipids, polymeric biosurfactants, neutral lipids or fatty acids (Banat et al., 2000; Franzetti et al., 2010).

Biosurfactants have some advantage over their commercially manufactured chemical surfactants because of their lower toxicity (pharmaceutical industry), biocompatibility, biodegradable nature and effectiveness at extreme temperature, $\mathrm{pH}$, salinity, as well as the ease of production (Mulligan and Gibbs, 2004; Ilori et al., 2005). Biosurfactants are more efficient critical micelle concentration (CMC) of biosurfactant is about 10-40 times lower than that of chemical surfactants, in other word, it requires lesser quantity than chemical surfactants to decrease surface tension (Desai et al., 1997). Previously, biosurfactant-producing microbes had been produced on haemolytic media without hydrocarbons (Mulligan et al., 1984) and the result indicated that it can serve as preliminary test for identification of related isolates. This test can be performed to determine the ability of bacterial colonies to induce haemolysis when grown on blood agar. A few biosurfactants are currently available in the market and efforts at discovering new ones are on top gear. Biosurfactants are useful in pharmaceutical, food, petroleum, detergent, agricultural, textile industries (Roy, 2017; Akbari et al., 2018). This study aimed to determine the 
amylase and biosurfactant activity of some Bacillus species obtained from agricultural soil.

\section{Materials and Methods}

\section{Sample collection}

Soil samples were collected from agricultural field of Adekunle Ajasin University, Akungba-Akoko, Ondo State, Nigeria from a depth of $10 \mathrm{~cm}-15 \mathrm{~cm}$ with the aid of a soil auger. Samples were transferred into sterile plastic bags and brought to the Microbiology Laboratory of the Department of Microbiology, Adekunle Ajasin University under aseptic conditions and stored in a refrigerator at $4^{\circ} \mathrm{C}$ for further studies.

\section{Isolation and identification of bacterial species}

The organisms were isolated by growing on a nutrient agar medium after which they were observed carefully for colony morphology with respect to colour, shape, size, nature of colony and pigmentation (Mishra and Behera, 2008). The isolates were Gram stained and observed under the light microscope (Vipul, 2011). The isolates were characterized biochemically using catalase, coagulase, methyl red, sugar fermentation and starch hydrolysis tests (Kaur et al., 2012). The organisms were identified using the Bergey's manual of determinative bacteriology, 9th edition (Olukunle, 2013; Adeoyo, 2019).

\section{Screening for amylase producing bacterial species}

Bacterial isolates were screened for amylolytic properties by starch hydrolysis test on starch agar plate with the following components (w/v): Starch (1.0\%), yeast extract $(0.05 \%), \mathrm{KCl}(0.01 \%), \mathrm{MgSO}_{4} .7 \mathrm{H}_{2} \mathrm{O}$ (0.05\%), $\mathrm{NaH}_{2} \mathrm{PO}_{4}(0.01 \%)$, agar $(1.5 \mathrm{~g})$, water $(100 \mathrm{~mL})$. The microbial isolates were streaked along a line on the starch agar plate and plates were incubated at $37^{\circ} \mathrm{C}$ for 48 hours. After incubation $1 \%$ iodine solution (freshly prepared) was used to flood the starch agar plate (Ashwini et al., 2011). Presence of blue-black colour around the growth indicated a negative result while a clear zone (halo) indicated a positive result. The isolates that produced clear zones (haloes) of hydrolysis were taken as amylase producers.

\section{Assay for amylase activity}

The enzyme assay was conducted using dinitrosalicylic acid (DNSA) assay method described by Miller (1959). A $100 \mathrm{~mL}$ nutrient starch broth was inoculated with 1 $\mathrm{mL}$ suspension of a bacterial isolate and incubated in a rotary incubator shaker at $37^{\circ} \mathrm{C}$ for 48 hours. After incubation, the nutrient starch broth was centrifuge at $10000 \mathrm{x} g$ for $15 \mathrm{~min}$ and the supernatant was used as cell free crude enzyme. A soluble starch (1\%, w/v) was added to a $10 \mathrm{~mL}$ citrate-phosphate buffer (pH 6.8) in a Schott bottle. The mixture was stirred with a magnetic stirrer until completely dissolved.

A $1 \mathrm{~mL}$ of each crude enzyme was added to a separate $1 \mathrm{~mL}$ substrate (performed in triplicate). The blank contained $2 \mathrm{~mL}$ buffer only. All samples were incubated at $37^{\circ} \mathrm{C}$ for $60 \mathrm{~min}$, followed by centrifugation at $10000 \times$ $g$ for 2 min. After centrifugation, a $1 \mathrm{~mL}$ supernatant was then withdrawn and transferred to a new test tube, and $1 \mathrm{~mL}$ DNSA reagent was added. This was followed by boiling for $5 \mathrm{~min}$ at $100^{\circ} \mathrm{C}$ and cooled on ice for $5 \mathrm{~min}$. A $2 \mathrm{~mL}$ of each of either blank, controls or samples was placed in a cuvette and the absorbance read with the aid of a spectrophotometer at a $540 \mathrm{~nm}$ wavelength. A unit of enzyme activity was expressed as 1 $\mu \mathrm{mol}$ of maltose equivalent released per minute per millilitre of enzyme solution. 
Screening for biosurfactant production from Bacillus species

Mineral salt medium (MSM) of minimal salt medium containing; $\mathrm{K}_{2} \mathrm{HPO}_{4}(1.0 \mathrm{~g})$, $\mathrm{MgSO}_{4} .7 \mathrm{H}_{2} \mathrm{O}(0.2 \mathrm{~g}), \mathrm{FeSO}_{4} .7 \mathrm{H}_{2} \mathrm{O}(0.05 \mathrm{~g})$, $\mathrm{CaCl}_{2} .2 \mathrm{H}_{2} \mathrm{O}(0.1 \mathrm{~g}), \mathrm{Na}_{2} \mathrm{MoO}_{4} .2 \mathrm{H}_{2} \mathrm{O}(0.001$ g), $\mathrm{NaCl}(0.03 \mathrm{~g})$, used engine oil $(1.0 \%$, $\mathrm{w} / \mathrm{v})$, and water $(1000 \mathrm{~mL}$ ) (Nayarisseri et al., 2018). A $100 \mathrm{~mL}$ of MSM was dispensed into each $250 \mathrm{~mL}$ Erlenmeyer flask, sterilized by autoclaving at $121^{\circ} \mathrm{C}$ for $15 \mathrm{~min}$ and inoculated with a loopful of each bacterial culture.

The experiment was performed in an incubator shaker for 72 hours at $150 \mathrm{rpm}$ (temperature $37^{\circ} \mathrm{C}$ ). After incubation, culture broth was centrifuged at $6000 \mathrm{rpm}$ for $15 \mathrm{~min}$. The supernatant was collected for various biosurfactant screening tests. Biosurfactant production was determined by three methods; blood haemolysis, oil spreading, and dropcollapse tests.

\section{Blood haemolysis test}

A 24-hour old culture of each isolate was streaked on blood agar plate. The plate was incubated for 72 hours at $37^{\circ} \mathrm{C}$. Each plate was observed for the presence of clear zone around each colony. A clear zone indicated the presence of biosurfactant.

\section{Oil spreading test}

A micropipette was used to take $10 \mu \mathrm{L}$ of used engine oil, added to the surface of $40 \mathrm{~mL}$ of distilled water into a Petri dish to form a tin oil layer. A $10 \mu \mathrm{L}$ of the crude biosurfactant was immediately dropped on the centre of the oil layer to form a clear zone. The result was read after 30 seconds, and a clear zone indicated the presence of biosurfactant (Morikawa et al., 1993; Walter et al., 2010).

\section{Drop collapse test}

A drop of the culture supernatant was placed carefully on an oil coated glass slide and was read after $1 \mathrm{~min}$. If the drop of supernatant collapsed and spread on the oil coated surface, it signifies the presence of biosurfactant (positive). The diameter of clear zone on the oil surface indicated the extent of biosurfactant activity (oil spreading activity) (Walter et al., 2010).

\section{Results and Discussion}

Isolation and identification of bacterial species

All isolates identified as Bacillus species were selected for further studies. The organisms were identified based on the characteristics observed with the use of Bergey's manual of determinative bacteriology. A total of ten (10) Bacillus species were identified from soil. These isolates include; two B. subtilis (AMY5 and AMY13), B. mycoides, two B. polymyxa (AMY2 and AMY12), B. azotoformans B. licheniformis, B. megaterium, B. pumilus, and B. cereus.

\section{Amylase producing Bacillus species}

Different Bacillus species showed varying enzyme activity on starch agar plates. The diameters of these microbes' hydrolytic zones range between 6 to $12 \mathrm{~mm}$ on agar plates. Plate a ( $B$. licheniformis) shows more hydrolytic zone than the other tested Bacillus species (Figure 1) (Table 1).

\section{Biosurfactant producing Bacillus species}

Table 2 shows that Bacillus licheniformis (AMY17) had the highest biosurfactant production capacity, followed by $B$. subtilis 
(AMY5), B. azotoformans, B. polymyxa (AMY24), B. cereus, and B. megaterium. Weak activity was observed with $B$. subtilis
(AMY13), B. pumilus and B. polymyxa while $B$. mycoides did not show any activity.

Table.1 Amylase activities of Bacillus species

\begin{tabular}{|c|c|c|c|}
\hline $\begin{array}{c}\text { Isolate } \\
\text { Code }\end{array}$ & Bacillus species & $\begin{array}{c}\text { Diameter of } \\
\text { hydrolytic zone } \\
(\mathbf{m m})\end{array}$ & $\begin{array}{c}\text { Amylase } \\
\text { activity } \\
(\boldsymbol{\mu m o l} / \mathbf{m i n} / \mathbf{m L})\end{array}$ \\
\hline AMY5 & B. subtilis & 10 & $0.89 \pm 0.021$ \\
\hline AMY10 & B. mycoides & 9 & $0.76 \pm 0.030$ \\
\hline AMY13 & B. subtilis & 7 & $0.33 \pm 0.016$ \\
\hline AMY2 & B. polymyxa & 8 & $0.44 \pm 0.007$ \\
\hline AMY24 & B. polymyxa & 9 & $0.62 \pm 0.029$ \\
\hline AMY26 & B. azotoformans & 11 & $1.02 \pm 0.023$ \\
\hline AMY17 & B. licheniformis & 12 & $1.12 \pm 0.035$ \\
\hline AMY9 & B. megaterium & 8 & $0.33 \pm 0.010$ \\
\hline AMY25 & B. pumilus & 7 & $0.30 \pm 0.016$ \\
\hline AMY8 & B. cereus & 6 & $0.27 \pm 0.014$ \\
\hline
\end{tabular}

Table.2 Biosurfactant production potential of Bacillus species

\begin{tabular}{|c|c|c|c|c|}
\hline Isolate Code & Organism & Haemolysis & $\begin{array}{c}\text { Drop } \\
\text { Collapse }\end{array}$ & Oil spreading \\
\hline AMY5 & B. subtilis & + & ++ & +++ \\
\hline AMY10 & B. mycoides & - & - & - \\
\hline AMY13 & B. subtilis & + & + & + \\
\hline AMY2 & B. polymyxa & + & - & - \\
\hline AMY24 & B. polymyxa & + & ++ & ++ \\
\hline AMY26 & B. azotoformans & + & + & +++ \\
\hline AMY17 & B. licheniformis & + & +++ & +++ \\
\hline AMY9 & B. megaterium & + & + & ++ \\
\hline AMY25 & B. pumilus & + & Nd & + \\
\hline AMY8 & B. cereus & + & ++ & ++ \\
\hline
\end{tabular}

Key: $+=$ positive result,$-=$ negative result, $\mathrm{nd}=$ not determined, $++=$ efficient, $+++=$ very efficient 
Figure.1 Screening for amylase enzyme production: (a) Bacillus licheniformis (AMY17); (b) Bacillus megaterium (AMY9)

(a)

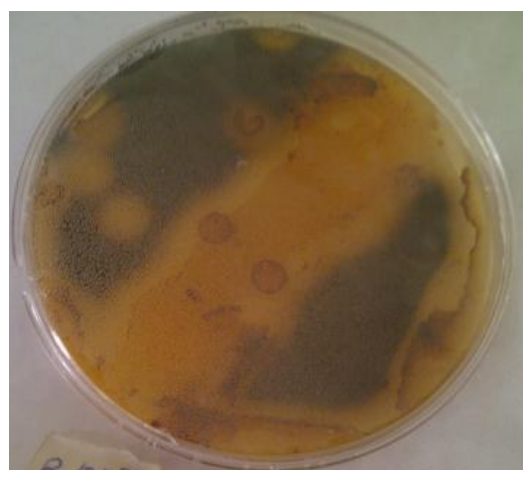

(b)

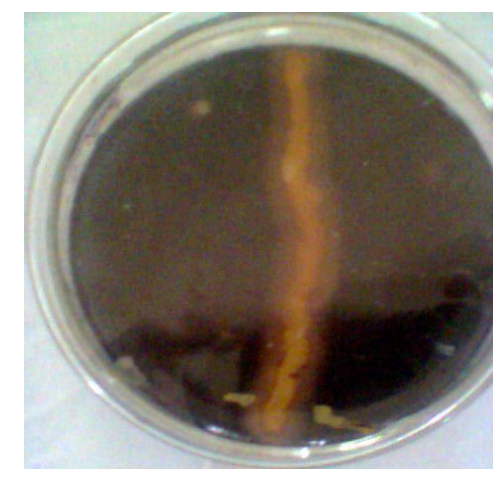

The study showed that ten (10) Bacillus species were isolated and identified from soil. They include; two B. subtilis (AMY5 and AMY13), B. mycoides, two $B$. polymyxa (AMY2 and AMY12), B. azotoformans $B$. licheniformis, B. megaterium, B. pumilus and $B$. cereus. These findings agree with the report of Pandey et al., (2000); Mishra and Behera (2008) who reported that some Bacillus spp. isolated from soil and water samples were capable of hydrolysing starch. These results also corroborate the study of Mohammed and Mastan (2013) who reported amylolytic potential of some bacteria isolated from agriculture fields of Bhimavaram, India. Bacillus licheniformis (AMY17) had the highest activity value of $1.12 \mu \mathrm{mol} / \mathrm{min} / \mathrm{mL}$ while Bacillus cereus (AMY8) had the least value of $0.27 \mu \mathrm{mol} / \mathrm{min} / \mathrm{mL}$.

Enzymes (for an example, amylase) from Bacillus species have been shown to contribute to improving nutrient digestibility and maintaining a beneficial gut microbiota in poultry birds (Latorre et al., 2016). Furthermore, the study revealed that soil is a rich source of microorganisms (particularly bacterial species) which can be used for amylase production. The results of starch-agar screening method correlate with the enzyme activity assay across all isolates tested. Thus to determine enzyme activity of a large number of bacterial cultures, agar screening method provides means of identifying the best isolate(s) and reducing the number of positive isolates to a sizable number. The exploration of Bacillus species as microbial sources for amylases production will continue to increase productivity in detergent, pharmaceutical, food and confectionery industries.

Also, the study revealed that Bacillus species have varied biosurfactant activities. Haemolysis test is a major screening method for identifying biosurfactant-producing bacteria, and oil spreading, drop collapse are among other confirmatory tests (Shoeb et al., 2015). From this study, B. licheniformis $B$. subtilis (AMY5), B. azotoformans, $B$. polymyxa (AMY24), $B$. cereus, and $B$. megaterium showed great potentials for biosurfactants production. These findings agree with the observation made on $B$. azotoformans by Adamu et al., (2015). Similar report was made by Ndibe et al., (2018) who reported the screening of biosurfactant-producing bacterial species obtained from River Rido, Kaduna, Nigeria. Moreover, Maneerat and Phetrong (2007) reported that $B$. subtilis and $B$. pumilus were among the bacterial species with biosurfactant activity. Consequently, the metabolic 
products of these indigenous microbes have contributed to a major breakthrough for bioremediation purposes and other industrial applications (Boboye et al., 2010; Olukunle, 2013; Akbari et al., 2018).

In conclusion, amylases have wide range of applications and the demand for these enzymes is increasing daily, it is obvious that studies on amylases and their usefulness have progressed well over the last few decades. Biosurfactants on the other hand are key components in the clean-up strategy for bioremediation due to their biodegradability and low toxicity. They are also useful in detergent industry because they are biodegradable, $\mathrm{pH}$ stable; low CMC and environmentally friendly. Bacillus species are among bacteria that have shown attractive potentials for production of these useful biomolecules. Further studies are needed to characterize and optimize the production under certain growth conditions such as $\mathrm{pH}$, temperature, carbon sources and nitrogen sources. Therefore, indigenous entrepreneurs and researchers are encouraged to invest in these important biomolecules that can benefit mankind, especially those from Bacillus species.

\section{References}

Adamu, A., Ijah, U.J.J., Riskuwa, M.L., Ismail, H.Y. and Ibrahim, U.B. 2015. Study on biosurfactant production by two Bacillus species. Int. J. Sci. Res. Know. 3:13-20.

Adeoyo, O.R. 2019. Plant growth-promoting potentials of some indigenous bacterial isolates. IOSR J. Pharm. Biol. Sci. 14(6):05-10.

Adeoyo, O.R., Pletschke, B.I. and Dames, J.F. 2019. Amylase production and optimization of culture conditions for some ericoid mycorrhizal fungi. Sci. Res. Annal. 10:50-57.
Akbari, S., Abdurahman, N.H., Yunus, R.M., Fayaz, F., Alara, O.R. 2018. Biosurfactants - a new frontier for social and environmental safety: a mini review. Biotechnol. Res. Inno. 2: 81-90.

Ashwini, K., Gaurav, K., Karthik, L. and Bhaskara, R. V. 2011. Optimization, production and partial purification of extracellular $\alpha$ - from Bacillus sp. Arch. Appl. Sci. Res. 3(1):33-42.

Banat, I.M., Makkar, R.S. and Cameotra, S.S. 2000. Potential commercial applications of microbial surfactants. Appl. Microbiol. Biotechnol. 53:495-508.

Bijttebier, A., Goesaert, H. and Delcour, J.A. 2007. Temperature impacts the multiple attack action of amylases. Biomacromolecules, 8:765-772.

Boboye, B., Olukunle, O. and Adetuyi, F. 2010. Degradative activity of bacteria isolated from hydrocarbon-polluted site in Ilaje, Ondo state, Nigeria. African J. Microbiol. Res. 4(23):2484-2491.

Bodour, A., Drees, K. and Maier, R. 2003. Distribution of biosurfactant-producing bacteria in undisturbed and contaminated arid southwestern soils. Appl. Environ. Microbiol. 69(6):32803287.

Cheng, K.B., Jian, Z. and Wang, Z. 2008. Emulsification properties of bacterial biosurfactants native to the Yellow River Delta on hexadecane and diesel oil. Int. J. Environ. Sci. 1(6):1079-1093.

Desai, J. D. and Banat, I. M. 1997. Microbial production of surfactants and their commercial potential. Microbiol. Mol. Biol. Rev. 61:47-64.

Fracchia, L., Cavallo, M., Martinotti, M.G. and Banat, I.M. 2012. Biosurfactants and bioemulsifiers biomedical and related applications present status and future potentials. Biomed. Sci. Eng. Technol. 14:325-370.

Franzetti, A., Tamburini, E. and Banat, I.M., 2010. Application of biological surface 
active compounds in remediation technologies. In: Sen, R. (Ed.), Biosurfactants: Adv. Exp. Med. Biol. 672:121-134.

Hussain, I. Siddique, F., Mahmood, M.S. and Ahmed, S.I. 2013. A Review of the microbiological aspect of $\alpha$-amylase production. Int. J. Agric. Biol. 15(5):1029-1034.

Ilori, M.O., Amobi, C.J. and Odocha, A.C. 2005. Factors affecting the production of oil Degrading Aeromonas sp. isolated from a typical environment. Chemosphere, 61:985-992.

Kaur, P. and Vyas, A. 2012. Characterization and optimal production of alkaline $\alpha$ amylase from Bacillus sp. DLB 9. African J. Microbiol. Res. 6(11):26742681.

Kumar, P. and Satyanarayana, T. 2009. Microbial glucoamylases: characteristics and applications. Crit. Rev. Biotechnol. 29: 225-255.

Lang, S. 2002. Biological amphiphiles (microbial biosurfactants). Curr. Opin. Colloid. Interface. Sc. 7(1-2):12-20.

Latorre, J.D., Hernandez-Velasco, X., Wolfenden, R.E., Vicente, J.L., Wolfenden, A.D., Menconi, A., Bielke, L.R., Hargis, B.M. and Tellez, G. 2016. Evaluation and selection of Bacillus species based on enzyme production, antimicrobial activity, and biofilm synthesis as direct-fed microbial candidates for poultry. Front. Vet. Sci. 3: 95.

Maneerat, S. and Phetrong, K. 2007. Isolation of biosurfactant-producing marine bacteria and characteristics of selected biosurfactant. Songklanakarin $J$. Sci. Technol. 29: 781-791.

Miller, G.L. 1959. Use of dinitrosalicylic acid reagent for determination of reducing sugar. Anal. Chem. 31:426-428.

Mishra, S. and Behera, N. 2008. Amylase activity of a starch degrading bacteria isolated from soil receiving kitchen wastes. African J. Biotechnol. 7(18):3326 - 3331.

Mohammed, B.D. and Mastan, S.A. 2013. "Isolation, characteristics and ccreening of enzyme producing bacteria from different soil sample" Int. J. Pharma. Biol. Sci. 4(3):813-824.

Morikawa, M., Daido, H., Takao, T., Murata, S., Shimonishi, Y. and Imanaka, T. 1993. A new lipopeptide biosurfactant produced by Arthrobacter sp. strain MIS 38. J. Bacteriol. 175: 6459-6466.

Mulligan, C., Cooper, D. and Neufeld, R. 1984. Selection of microbes producing biosurfactants in media without hydrocarbons. J. Fermentation Technol. 62(4):311-314.

Mulligan, C.N. and Gibbs, B.F. 2004. Types, production and application of biosurfactants. Proc. Indian Natn. Sci. Acad. 70(1):31-55.

Muralikrishna, G. and Nirmala, M. 2005. Cereal $\alpha$-amylases an overview, Carbohydrate Polymers 60:163-173.

Natasa, B., Jordi, R., Josep, L.S. and Zoran, V. 2011. Production and properties of the highly efficient raw starch digesting $\alpha$-amylase from a Bacillus licheniformis ATCC 9945. Biochem. Eng. J. 53(2):203-209.

Nayarisseri, A., Singh, P. and Singh, S.K. 2018. Screening, isolation and characterization of biosurfactant producing Bacillus subtilis strain ANSKLAB03. Bioinformation 14(6): 304-314.

Ndibe, T.O., Eugene, W.C. and Usman, J.J. 2018. Screening of biosurfactantproducing bacteria isolated from River Rido, Kaduna, Nigeria. J. Appl. Sci. Environ. Manag. 22: 1855-1861.

Nidhi, G., Gupta, J.K. and Soni, S.K. 2005. A novel raw starch digesting thermostable $\alpha$-amylase from Bacillus sp. I-3 and its use in the direct hydrolysis of raw 
potato starch. Enz. Microbial Technol. 37:723-734.

Oliveira, A., Oliveira, L., Andrade, J. and Junior, A. 2007. Rhizobia amylase production using various starchy substances as carbon substrates. Brazilian J. Microbiol. 38:208-216.

Olukunle, O.F. 2013. Characterization of indigenous microorganisms associated with crude oil-polluted soils and water using traditional techniques. Microbiol. J. 3:1-11.

Pandey, A., Nigam, P., Soccol, C.R., Soccol, V.T., Singh, D. and Mohan, R. 2000. Advances in microbial amylases. Biotechnol. Appl. Biochem. 31: 135-52.

Parka, G.T. and Son, H.J. 2007. Keratinolytic activity of Bacillus megaterium F7-1, a feather-degrading mesophilic bacterium. Microbiol. Res. 164:478485.

Perfumo, A.; Smyth, T. J. P.; Marchant, R. and Banat, I. M. 2010. Production and roles of biosurfactants and bioemulsifiers in accessing hydrophobic substrates. In: Timmis, K. N. (Ed.). Handbook of hydrocarbon and lipid microbiology. Berlin Heidelberg:
Springer-Verlag. pp. 1501-1512.

Rangaswami, G. and Bagyarag, D.J. 2004. Agricultural Microbiology. PrenticeHall of India Pvt. Ltd. ISBN 81-2030668-6. 440 pages.

Roy, A. 2017. A review on the biosurfactants: properties, types and its applications. Fund. Renew. Ener. Appl. 8: 248-253.

Shoeb, E. N., Ahmed, J., Akhter, U., Badar, K., Siddiqu, K.F., Ansari. 2015. Screening and characterization of biosurfactant-producing bacteria isolated from the Arabian Sea coast of Karachi. Turkish J. Biol. 39:210-216.

Vipul, V. 2011. Amylase production and purification from bacteria isolated from a waste potato dumpsite in district Farrukhabad U.P State India. Euro. J. Exp. Biol. 1(3):107-113.

Walter, V., Syldatk, C. and Hausmann, R. 2010. Screening concepts for the isolation of biosurfactant producing microorganisms: in biosurfactants, Sen, R. (Ed.). Landes Bioscience and Springer Science + Business Media, Berlin/Heidelberg, Germany. 1:1-13.

\section{How to cite this article:}

Olusegun Richard Adeoyo. 2020. Amylase and Biosurfactant Production from Bacillus species. Int.J.Curr.Microbiol.App.Sci. 9(05): 3183-3191. doi: https://doi.org/10.20546/ijcmas.2020.905.378 